\title{
RESULTS IN THE TREATMENT OF SACRAL CHORDOMA
}

\author{
V.F. Konovalenko ${ }^{1}$, V.V. Protsenko ${ }^{2}$, V.S. Chorneyi ${ }^{3}$ \\ ${ }^{1}$ R.E. Kavetsky Institute of Experimental Pathology, Oncology and \\ Radiobiology of National Academy of Sciences of Ukraine, \\ ${ }^{2}$ Institute of Traumatology and Orthopedics of NAMS of Ukraine, \\ ${ }^{3}$ Bogomolets National Medical University, Ministry of Ukraine \\ Kyiv, Ukraine
}

\section{INTRODUCTION}

Chordoma - a malignant, slowly growing tumor that develops from chord residues, is localized mainly in the lumbo sacral junction. It occurs in 2,5-4\% of cases of all primary malignant bone neoplasms [2]. Men get sick 1,5-2 times more often than women [1]. Clinically manifested dysfunction of the pelvic organs: intestines, bladder, impaired sensitivity and paresis of the lower extremities. Often the tumor is determined by rectal examination [5]. Differential diagnosis of sacral chordoma, most often carried out with chondrosarcoma and metastatic lesion $[3,4]$. Treatment of chordoma is usually combined, which includes: surgery and radiation therapy.

\section{MATERIALS AND METHODS}

61 patients were treated with chordoma sacrum. The first group consisted of 35 patients who underwent only surgical treatment in the volume of the sacral resection at the $S 3$ level, of which radical ablastic surgery was performed in 26 patients, and non-radical non-ablative -9 . The second group consisted of 26 patients who underwent combined treatment. In the preoperative period, all 26 patients underwent radiation therapy on the sacral tumor at a total focal dose (TFD) of 20 grays. In the postoperative period, $6 \mathrm{pa}$ tients with non-elastic and 4 patients with non-radical surgery were given radiation therapy in TFD 40 gray.

\section{RESULTS}

As a result of the surgical treatment of 35 patients of the first group, $6(17 \%)$ patients died in the early postoperative period due to various complications (acute cardiovascular insufficiency, pulmonary embolism, urosepsis, pelvioperitonitis). Therefore, long-term results were evaluated in 29 patients. Recurrences of chordoma were observed in $25(86,2 \%)$, metastases mostly in the lungs in $12(34,3 \%)$ patients. Threeyear survival was $45,3 \pm 1,8 \%$, five-year $-37,7 \pm 2,3 \%$. In the second group of 26 patients who received the combined treatment, 2 patients died in the postopera-
Article history:

Received 26 February 2019

Received in revised form 17 March 2019

Accepted 25 March 2019

tive period, so long-term results were evaluated in 24 patients. Recurrences of chordoma were observed in $9(37,5 \%)$ patients. Three-year survival in the second group was $90,0 \pm 0,8 \%$, five-year $-76,1 \pm 1,1 \%$.

\section{DISCUSSION}

In the surgical treatment of sacral chordoma, the lethality of patients is usually due to tumor recurrences with local complications and progression of the disease with distant metastases.

\section{CONCLUSIONS}

Taking into account the results obtained, it can be said that the combined method of treatment is more effective in treating patients with chrodoma of the sacrum, since the number of tumor recurrences has decreased and the survival rate of patients has increased.

\section{REFERENCES}

1. Atlas of Muscoloskeletal Tumors and Tumorlike Lesions: The Rizzoli Case Archive / P.Picci, M.Manfrini, N. Fabbri, M. Gambarotti, D. Vanel (Eds.), 2014, XXII. - 387 p., 226 illus., 173 illus. in color.

2. Benign notochordal cell tumors: a comporative histological study of benign notochordal cell tumors, classic chondromas, and notochordal vestides of fetal intervertebral discs / T. Yamaguchi, S. Susuki, H. Ishiiva [et al.] //Am. J. Surg. Patho. - 2004. - Vol.28. P. 756-761.

3. Brachyury, a crucial regulator of notochordal development, in a novel biomarker for choredomas /S. Vugovic, S. Henderson, N. Presnau [et al.] // J. Pathol. - 2006. - Vol. 209, №2. - P. 157-165.

4. Immunohistochemical comparison of chordoma with chondrosarcoma, myxopapillary ependymoma, chondroid meningioma / H.Y. Cho, M. Lee, H. Takei [et al.] // Appl. Immunohistochem. Mol. Morphol. 2009. - Vol. 17, №2. - P. 131-138.

5. Operative management of sacral chordoma // B.Funch, I.D.Dickey, Yaszemski M.J. [et al.] / J.Bone Joint Surg. Am. - 2005. - Vol.87, №10. P. 2211-2216. 